\title{
Occurrence of Emerging Contaminants in Water and Bed Material in the Missouri River, North Dakota, 2007
}

\author{
By William C. Damschen and Robert F. Lundgren
}

The U.S. Geological Survey (USGS), in cooperation with the Standing Rock Sioux Tribe, conducted a reconnaissance study to determine the occurrence of emerging contaminants in water and bed sediment within the Missouri River upstream and downstream from the cities of Bismarck and Mandan, North Dakota, and upstream from the city of Fort Yates, North Dakota, during September-October 2007. At each site, water samples were collected twice and bed-sediment samples were collected once. Samples were analyzed for more than 200 emerging contaminants grouped into four compound classeswastewater compounds, human-health pharmaceutical compounds, hormones, and antibiotics. Only sulfamethoxazole, an antibiotic, was present at a concentration higher than minimum detection limits. It was detected in a water sample collected downstream from the cities of Bismarck and Mandan, and in bed-sediment samples collected at the two sites downstream from the cities of Bismarck and Mandan and upstream from Fort Yates. Sulfamethoxazole is an antibiotic commonly used for treating bacterial infections in humans and animals.

\section{Introduction}

Tribal members of the Standing Rock Sioux Reservation are concerned about the quality of water on the reservation and that some of the drinking water consumed on the reservation is adversely affecting human health (Damschen and Lundgren, 2007). Emerging contaminants are chemical and microbial materials that have the potential to enter the environment and cause known or suspected adverse ecological and (or) humanhealth effects but that are not commonly monitored in the environment. Emerging contaminants are materials commonly derived from municipal, agricultural, and industrial wastewater sources and pathways and can be various manufactured and natural organic compounds, such as pharmaceuticals, steroids, surfactants, flame retardants, fragrances, plasticizers and other chemicals (Focazio and others, 2008). Some of these materials entering the environment have known ecological and human health risks; however, the health risks for a large number of these materials individually and as mixtures are not currently known.

\section{Sampling Locations}

Water and bed-sediment samples were collected at three sites on the Missouri River: upstream and downstream from Bismarck and Mandan wastewater treatment plants, and upstream from the Missouri River Intake water treatment facility in Fort Yates, North Dakota (table 1 and figure 1). At each site, water samples were collected twice (September and October) and bed-sediment samples were collected once (October). Samples were analyzed for emerging contaminant materials that were grouped into the following categories: wastewater compounds in water, human-health pharmaceutical compounds in water, hormones in water, antibiotics in water, waste indicators in solids, hormones in solids, and antibiotics in solids.

\section{Methods}

Samples were collected and processed using standard USGS techniques (U.S. Geological Survey, variously dated). Where possible, water samples were collected using width- and depthintegrating procedures. The bed-sediment

Table 1. Sampling site information.

\begin{tabular}{clc}
\hline Sampling site & USGS station number & \multicolumn{1}{c}{ Site name } \\
\hline 1 & 465245100530500 & $\begin{array}{c}\text { Missouri River above Bismarck/Mandan, } \\
\text { North Dakota }\end{array}$ \\
2 & 464445100493500 & $\begin{array}{c}\text { Missouri River below Bismarck/Mandan, } \\
\text { North Dakota }\end{array}$ \\
3 & 460533100371900 & $\begin{array}{c}\text { Missouri River above Fort Yates, North } \\
\text { Dakota }\end{array}$ \\
\hline
\end{tabular}




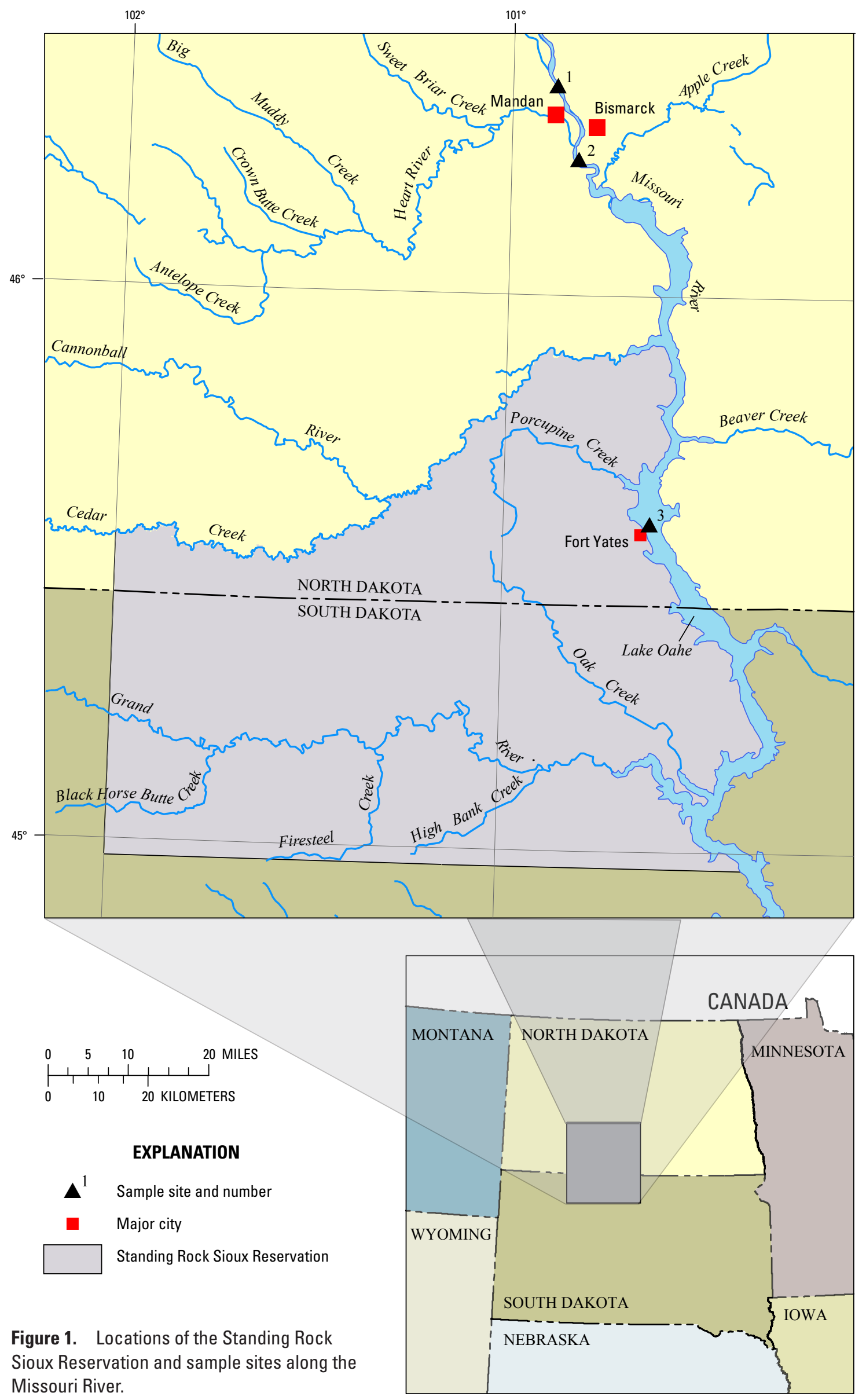




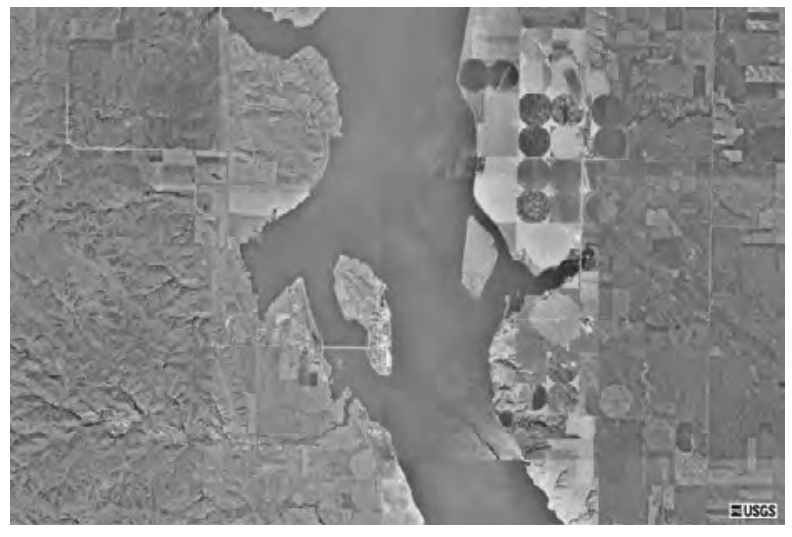

Aerial photograph of Fort Yates, North Dakota.

samples were collected from locations that adequately represented the water body of interest. Special procedures, such as avoiding use of insect repellents, sunscreen, tobacco, caffeine, and pharmaceutical drugs by the sampling team, were adhered to during sample collection (U.S. Geological Survey, variously dated).

Analyses for 68 wastewater compounds in water, 16 human-health pharmaceutical compounds in water, 32 hormones in water, 61 waste indicators in solids, and 32 hormones in solids were performed at the USGS National Water Quality Laboratory in Denver, Colorado (Zaugg and others, 2002; Burkhardt and others, 2006; Furlong and others, 2008). Analyses for 33 antibiotics in water and solids were performed at the USGS Organic Geochemistry Research Laboratory in Lawrence, Kansas, using methods modified from Meyer and others (2007) and Jacobson and others (2004).

\section{Analytical Results}

Analytical results indicated no compound concentrations higher than minimum detection limits with the exception of one antibiotic compound concentration. Sulfamethoxazole was detected in three separate samples: one water sample collected from site 2 (0.014 micrograms per liter), a bed-sediment sample from site 2 (28 micrograms per kilogram), and a bed-sediment sample from site 3 (2.3 micrograms per kilogram). Sulfamethoxazole is an antibacterial sulfonamide that is used to treat diseases such as bronchitis, middle-ear infection, urinary tract infection, conjunctivitis, malaria, toxoplasmosis, and traveler's diarrhea. It is also a widely prescribed veterinary antibiotic used to treat diseases and infections and is included in feed additives to promote growth and weight gain of food animals (National Research Council, 1999).

The data from this study are stored in the USGS National Water Information System database and are available online at http://nwis.waterdata.usgs.gov/nd/ nwis/qw

\section{References}

Burkhardt, M.R., Zaugg, S.D., Smith, S.G., and ReVello, R.C., 2006, Determination of wastewater compounds in sediment and soil by pressurized solvent extraction, solid-phase extraction, and capillary-column gas chromatography/mass spectrometry: U.S. Geological Survey Techniques and Methods, book 5, chap B2, 33 p.

Damschen, W.C., and Lundgren, R.F., 2007, Water, bed-sediment, and fishtissue quality within the Standing Rock Sioux Reservation, North Dakota and South Dakota, September 2006: U.S. Geological Survey Scientific Investigations Report 2007-5268, 29 p.

Focazio, M.J., Kolpin, D.W., Barnes, K.K., Furlong, E.T., Meyer, M.T., Zaugg, S.D., Barber, L.B., and Thurman, E.M., 2008, A national reconnaissance of pharmaceuticals and other organic wastewater contaminants in the United States-II. Untreated drinking water sources: Science of the Total Environment, v. 402, no. 2-3, p. 201-216.
Furlong, E.T., Werner, S.L., Anderson, B.D., and Cahill, J.D., 2008, Determination of human-health pharmaceuticals in filtered water by chemically modified styrene-divinylbenzene resin-based solid-phase extraction and high-performance liquid chromatography/mass spectrometry: U.S. Geological Survey Techniques and Methods, book 5, chap. B5, 56 p.

Jacobsen, A.M., Halling-Sørensen, Flemming I.B., and Hansen S.H., 2004, Simultaneous extraction of tetracycline, macrolide and sulfonamide antibiotics from agricultural soils using pressurised liquid extraction, followed by solid-phase extraction and liquid chromatography-tandem mass spectrometry: Journal of Chromatography, v. 1038 , Is. $1-2$, p. 157-170.

Meyer, M.T., Lee, E.A., Ferrell, G.M., Bumgarner, J.E., and Varns, Jerry, 2007, Evaluation of offline tandem and online solid-phase extraction with liquid chromatography/electrospray ionization-mass spectrometry for analysis of antibiotics in ambient water and comparison to an independent method: U.S. Geological Survey Scientific Investigations Report 2007-5021, 28 p.

National Research Council, 1999, The use of drugs in food animals: Washington, D.C., National Academy Press, $253 \mathrm{p}$.

U.S. Geological Survey, variously dated, National field manual for the collection of water-quality data: U.S. Geological Survey Techniques of Water-Resources Investigations, book 9, chaps. A1-A9, available online at http://pubs.water. usgs.gov/twri9A

Zaugg, S.D., Smith, S.G., Schroeder, M.P., Barber, L.B., and Burkhardt, M.R., 2002, Methods of analysis by the U.S. Geological Survey National Water Quality Laboratory-Determination of wastewater compounds by polystyrene-divinylbenzene solid-phase extraction and capillarycolumn gas chromatography/mass spectrometry: U.S. Geological Survey Water-Resources Investigations Report 01-4186, 37 p. 